cussed and changes in international practice recommended.

The work of the Aerological Commission has grown in importance owing to the increase in the volume of data relating to the free atmosphere. The regular meetings of the Commission considered, inter alia, definitions and specifications of water vapour in the atmosphere, values for certain physical constants in common use and the operation of meteorological reconnaissance flights ; but additional sessions were arranged for lectures and discussions at which the trends of modern research were studied.

The increased attention which economic concerns are devoting to meteorology was reflected in the work of the Climatological Commission, which formed a permanent Sub-Commission to examine the applications of climatology to health and industry. The remaining Commissions--those for Hydrology, Agricultural Meteorology, Bibliography and Publications, and for the Projection of Charts-also held successful meetings and made valuable recommendations.

The technical commissions finished their work in Toronto on September 15, and a week later the Conference of Directors opened in Washington. The agenda contained, in addition to some four hundred resolutions submitted by the technical commissions, a proposal to form a World Meteorological Convention, and another to seek affiliation to the United Nations.

With regard to the Convention, the International Meteorological Organisation has hitherto been a semi-official association of Directors of Meteorological Services, but the increased importance of meteorology in a number of directions has led to a widespread belief that the Organisation should be replaced by an inter-governmental body which would be in a more favourable position to enlist official support. The proposal for a Convention gave rise to protracted discussion, and it was clear that some of the delegates were not without misgivings as to the wisdom of a change in the existing organisation. The subject was treated with the utmost frankness, and eventually, after proper safeguards to ensure the equality of meteorological services on technical matters had been provided, a World Meteorological Convention was drafted and signed by thirty-three countries. It will come into force on ratification by thirty countries, and the World Meteorological Organisation will take over the assets and obligations of the existing International Meteorological Organisation, which will cease to exist.

A decision to seek affiliation to the United Nations was quickly reached once the subject of the Convention had been settled. With the assistance of delegates from the United Nations who were present at the Conference, a draft agreement was drawn up which, after approval by a majority of members of the International Meteorological Organisation, will be submitted to the United Nations. If this is accepted, the World Meteorological Organisation will be linked with the United Nations as a specialized agency.

On the technical side, the Conference approved more than two hundred resolutions of the technical commissions, and formed two new commissions, one to study radio-electric meteorology and the other to deal with problems of Arctic and Antarctic meteorology. At two sessions, which were attended by delegates from the International Civil Aviation Organisation, measures designed to co-ordinate the activities of the two Organisations in meteorological affairs were agreed.
The Toronto and Washington meetings, considered either separately or as a whole, were most successful, and well repaid the sustained effort that was required from the delegates. Considerable progress was made both on the technical side and in improving the machinery for applying meteorology to human welfare. One of the most important results was, of course, the signing of the World Meteorological Convention. This decision to effect a fundamental change in the status of the International Meteorological Organisation illustrates the determination of members to adapt the Organisation to modern world conditions. Another promising feature was the emphasis placed upon research, and at the meetings of the technical commissions it was gratifying to notice that the delegates included a high proportion of younger men of science of great ability and originality of outlook.

\section{THE TEAK FORESTS OF BURMA}

\author{
By Prof. E. P. STEBbiNG \\ University of Edinburgh
}

$T$ HERE is probably more romance wrapped up in the history of the great teak forests of Burma, without the addition of the latest war chapter of the Fourteenth Army, than in any other afforested region of similar size in the world. To a large extent the teak tree is itself responsible. Our acquaintance with these forests, so far as the British personally are concerned, commenced with the inquiries into their resources made by the Government after the acquisition for political reasons of the Tenasserim and Martaban Provinces, ceded to the British by Burmese under the Treaty of Yandaboo early in the year 1826. Although the British in India and the Admiralty at home had obtained a certain amount of teak from Rangoon and Moulmein, the largest amount utilized up to this time came from the accessible parts of the teak forests in Malabar on the west coast of Madras. These, in the hands of timber exploiters, were to a great extent cut out by 1830 .

Dr. Wallich, superintendent of the Botanic Gardens, Calcutta, was sent to the new Province to report on the botanical features of the forests, and also on their potential possibilities both commercially and for the provision of teak timber required for military purposes. There were great stores of teak in the forests, he said. $\mathrm{He}$ advised, in view of the destruction caused in the Malabar forests by unchecked exploitation, that Government should declare its ownership of all teak and that the forests should be managed by Government so as to ensure against their ruin. He added, "No forest exists which can, with propriety, be called inexhaustible - at least none that is liable to constant and extensive demands for timber". The advice was not adopted by the commissioner-in-charge of the new Province. A system of leases was instituted under which the lessee was allowed to take up a block of forest on one or other of the rivers and operate as he liked; the few rules issued were generally disregarded. Moulmein, from little more than a large village, soon became an important town, and within twenty years the whole of the population were immersed in the teak industry to the neglect of any attempt at an improved and extended area under agriculture. A score of years after the annexation, 
the greater part of the accessible forests had been treated in a fashion similar to the Malabar ones.

The licence method had proved to be a difficult one to supervise and, in the late forties, the Deputy Governor suggested to the Court of Directors that long 99-year leases should be given out in order to interest the licensees in growing teak, a long-term project. Later he earnestly recommended the Court of Directors to give authority to sell the whole of the teak forest lands in tracts of convenient extent and to convey to the purchasers a complete title. The Court of Directors was mercifully too wide-visioned to adopt this suggestion.

The Second Burmese War took place in 1852, the outcome being the annexation of the Province of Pegu on December 20, 1852. Rangoon was the capital, having been founded by the Alompra dynasty in 1775 . It had been the principal mart for the export of teak timber for nearly a century, teak being the chief staple industry of the port at that time. The teak tree had been proclaimed a royal tree by this dynasty, and was a royal monopoly, as had been the case with Tippoo Sahib in Southern India, and in the neighbouring Travancore and Cochin States. Follow. ing this precedent, soon after the annexation a notification was issued by the Governor-General that all the forests were the property of Govermment and no general permission to cut timber therein would be granted to anyone. But differences of opinion soon arose between the commissioner appointed to administer the Province and the forest officer. The GovernorGeneral had proclaimed the teak public property, but both the above officials agreed that the Tenasserim royalty of 15 per cent only should be levied on all timber brought down river to Rangoon. The differences between them were on other issues. This led to the famous minute from the Governor-General, Lord Dalhousie, which has been termed "The Charter of the India and Burma Forests". In this he directed attention to his former notification on the ownership of teak, which laid down that the teak timber should be retained as State property. In effect, Lord Dalhousie laid down that the forests were the property of the State, which meant of the public, and that the material in them should be sold at a price the market was prepared to pay-that the system by which the timber merchant made the greatest profit must cease. In the past, big timber firms had been in the habit of getting a permit to take up blocks of teak forest and work them out for teak, paying the Crown a lump sum down and an agreed price per tree or log extracted. The profits, as in the case in Moulmein, of the timber speculators had been excessive, while the activities of the whole people were confined to one business, to the detriment of agriculture.

Lord Dalhousie found a man in Dr. (later Sir Dietrich) Brandis to give effect to his proclaimed policy. Brandis was appointed superintendent of the Pegu Forests in January, 1856, and shortly after to those of Tenasserim. The first step was to put an end to indiscriminate felling in the forests by obtaining some figure of their volume-value in teak, to enable him to prescribe the volume per unit of area which could be safely cut without overfelling in the forest. $\mathrm{He}$ instituted his now well-known 'strip surveys'marching through the forests on a line previously laid down and measuring up on either side all teak trees on a $50 \mathrm{ft}$. strip. He made four girth classes : $6 \mathrm{ft}$. and more ; 4 ft. 6 in. to $6 . \mathrm{ft}$; $3 \mathrm{ft}$. to $4 \mathrm{ft}$. 6 in. ; less than $3 \mathrm{ft}$. An area of 30 square miles was covered by these linear surveys, on which 2,423 trees of $6 \mathrm{ft}$. and more had been counted, or an average of eighty trees per square mile. It was estimated that the teak in Pegu was scattered over an area of 7,000 square miles, giving a grand total of 385,000 first-class trees of $6 \mathrm{ft}$. and more. On this he based the number of trees he could mark for sale each year. The danger of ignorant over-felling was past. The teak had to be girdled when marked and stand in the forests for two to three years to dry; since green teak will not float, and much of the teak was transported from the forest to the market at Rangoon by floating down the rivers. Later calculations of the volumes of teak in the forests made by a more numerous staff proved that Brandis' figures were extraordinarily accurate, considering the rough methods he had to use.

Brandis considered that Government must show the way and prove that the forests could be worked efficiently, the trees felled and logs extracted with the minimum of damage, while, at the same time, the prices received for the timber would repay all charges of felling and extraction and show a handsome surplus. Brandis started work, hiring contractors to fell the timber, drag it to the floating streams and raft it to the sale depots. Local contractors and others more powerful at a distance put every obstacle in the way of the new departure, and it took a man of Brandis' forceful nature to fight and live down this concentrated opposition. The Government was by no means convinced as to the soundness of Brandis' proposition. In its view the first necessitv was to ensure that the annual amount of teak timber required by the Government services was fortheoming without any danger of deficiencies: the second that in the first few years working the costs were larger than the receipts. The powerful timber contractors carried the matter to the Privy Council; but the Government's view was upheld in its main contention-that the teak forests were public ownership and should not be worked unchecked by timber exploiters. Brandis soon saw that it would be impossible to work such large areas departmentally, owing to the want of staff and other reasons. He therefore suggested that 12-15 year leases should be granted to approved timber contractors for a definite forest area, the trees to be removed to be marked and girdled by the Forest Department, and the lease be subject to certain definite conditions as regards methods of felling, extraction, etc. This practice is still in force. The other directions in which a true forest administration was commenced in Burma are by now well known. In 1861 Brandis was transferred to India and appointed first inspector-general of forests to the Government of India, and in 1864 the Indian (includ. ing Burma) Forest Service was formed, to be officered by men trained in Europe.

The Third Burma War and the annexation of Upper Burma might be said to have witnessed the third advance in forestry progress in Burma. The political reasons are not under consideration. The proclamation of the annexation of Upper Burma in January 1886 was made just sixty years after the annexation of Tenasserim. The new territory placed an enormous area of potential teak and other forests under the Forest Department, the staff of which was far too small to deal with the task. However, progress was made in a remarkably short time by transferring some officers from India.

Once again, and for the last time, the big timber contractors sought to get a free hand in the exploitation of the teak forests in this new Province. Once again the fight was carried to the Privy Council. 
But the Inspector-General of the day, Ribbentrop, who had had long experience in Burma as a forest officer, won his case : and all the more easily since it was possible to point to the Pegu Forests thirty years after Brandis had stopped unchecked fellings, and compare them with the position of the cut-out Malabar Forests in 1830 and Tenasserim in 1845.

The reservation of the forests went steadily forward during the last thirty years of the century. Another matter, first enunciated by Brandis, but not actually put into practice by him, was to make use of the nomadic shifting cultivation habits of the Shans and Karens by getting them to sow teak seed or plant in teak plants with their (shifting) cultivation. The iaea was not new : both in France and Germany the practice had been in force in the past. In Burma the term 'taungya' had been given to the method, from the Burmese word for shifting cultivation. Considerable patches of young teak poles existed at the end of the century about the country, but as no record or map had been kept they had mostly been lost to sight in the encompassing forest. In the early years of the present century the method fell into abeyance, but was revived at Tharrawaddy during the second decade of the century with very great success. This practice was adopted in the case of sal in Bengal and spread throughout India and out to Africa and other parts of the Empire. I saw it in practice by the French forest officers in the Ivory Coast in 1934, copied from the work of British officers in Nigeria.

Forest administration based on sound sylvicultural management and finance made great progress in Burma during the first two decades of the present century. The First World War proved the soundness of the foundations laid. Great demands were made upon Burma to supply the requirements in Mesopotamia, and several other species besides the now commonly used ones, teak and pyinkado, were utilized, some remaining on the market afterwards.

Since the first successful attempt at protecting an Indian teak forest from fire (in the Central Provinces) during the hot-weather season in India had passed successfully, a fire protection system had been devised for all the reserved forests in India and Burma. Fires occurred annually; but the wholesale scale of former times had come to an end. At the beginning of the present century fire protection in the moist teak forests in Burma was called in question. It was found that a low growth of evergreen shrubs covered the forest floor, through which no teak seedling could penetrate. Careful examination showed this to be true in both the moist teak and moist sal areas (in India). Fire protection was, therefore, given up save in the very young new woods. As an outcome, a practice termed 'early burning' was adopted, with good results.

To the trained and experienced forest officer, the test of the efficiency, thoroughness and permanency of a forest administration can be studied in one way and one way only-by the presence of working plans in the area of forest administered, the degree of intensity on which the working plans are drawn, and the manner in which they are worked. A forest under a well-drafted working plan, which has passed the scrutiny of the higher forest authority, and been sanctioned by the civil administration of the country, is as safe as man can make it. Such plans laying down the whole management of the forest are usually drawn up for ten-year periods. Burma holds a high place in this important practice of the correct adminis- tration of a forest. It is understood that no serious damage to the teak forests was done during the Second World War. Teak is chiefly a timber felled for export. During the War, all teak exports ceased and the Japanese did not undertake any serious fellings in the teak areas, only cutting what they required for their military forces. In 1939 it may be said that Burma could show as fine a series of working plans for great forests from, to quote examples, the plans for South Toungoo and Tavoy in Tenasserim, South Pegu, Zigon and the Northern Shan States, to the Mu and Katha Forests and those of the Chindwin in the north. The work is not finished. For example, some of these working plans have been revised or re-written several times since the early days of the first real working plan (omitting the 'paper' or purely volume statistic plans of Brandis' day) of the early 'eighties. Others are first plans, as, for example, the Mu working plan drawn up for the period 1929-30 to 1938-39.

The total area of the Government reserved forests in Burma in 1938-39 on March 31, 1939, was $20,100,221$ acres. The total volume of teak timber felled during 1938-39 was 1,402,548 cubic feet. The total volume of teak timber exported in 1938-39 was as follows in cubic tons: teakwood, 203,596; teak sleepers, 609 ; teak squares, 59,385 ; teak conversions, 137,401; teak round logs, 6,209; total, 407,200 cubic tons; teak keys (in tons), 4,753.

That long role of British forest officers which commenced with Brandis more than ninety years ago is now to terminate. They have done a magnificent work for Burma, and have left a great heritage to the Burmans. The latter are now going to take full control of this finely tempered forest administration and these enormously valuable forest estates. In bidding a farewell we can but wish them all success, coupled with the warning that there is no other property in the world which can be so insidiously depreciated, since it inevitably takes a term of years before the effects are perceivable or can be appreciated.

\section{OBITUARIES \\ Dr. Cyril Strickland}

Dr. Cyril Strickland, who died on November 3 in Jersey, aged sixty-six, was born in Cape Colony. Ho was educated at St. Andrew's College, Grahamstown, and at Oundle School.

After graduating with first-class honours from Caius College, Cambridge, he went to St. Bartholomew's Hospital, London, but before completing his medical course he accepted an invitation to study protozoology at Cambridge under Prof. G. H. F. Nuttall, whose assistant he became. During his tenure of this appointment he found time to take his degree in medicine. He also made the interesting and important discovery that the trypanosome of the rat was normally transmitted from rat to rat through the alimentary route by the mastication of infected fleas and not by the bites of the fleas as had previously been assumed.

In 1912 he went to Malaya to work on the malaria problem on behalf of the Government of the Federated Malay States.

Dr. (now Sir) Malcolm Watson had already been conspicuously successful in controlling by drainage the malaria of the flat coastland of Malaya; but the disease in the upland jungle remained a baffling problem. Strickland has described how, in the 